\title{
BALANCING EFFECT OF LARCH PLANTATIONS (LARIX KAEMPFERI) ON UNDERSTORY PLANT DIVERSITY IN A SUB- TROPICAL FOREST ECOSYSTEM, CHINA
}

\author{
LI, Y. ${ }^{*}$ - ZOU, D. - REN, B. - DING, X. - BIAN, H. - WANG, J. \\ College of Bioscience and Biotechnology, Hunan Agriculture University \\ Changsha 410128, China \\ *Corresponding author \\ e-mail: liyouzhi2004@163.com \\ (phone: +86-731-8467-3600) \\ (Received $7^{\text {th }}$ Jan 2016; accepted $17^{\text {th }}$ May 2016)
}

\begin{abstract}
We evaluated effects of larch plantations on understory plant diversity by conducting large-area investigations on three types of tree stands, including pure larch plantations (Larix kaempferi, an exotic coniferous deciduous tree species), pure liriodendron plantations (Liriodendron chinense, a native broad-leaved deciduous tree species) and mixed stands (L. kaempferi and L. chinense) in a subtropical forest. A total of 19 plantation areas, 684 quardrats, and 10 environmental factors [elevation, slope, ratio of light availability (RLA), soil pH, soil water content (SWC), soil organic matter (SOM), soil total nitrogen (STN), soil total phosphorus (STP), soil total potassium (STK)] were surveyed. Species richness and Shannon's diversity were statistically similar in the three types of tree stands but Shannon's diversity was somewhat higher in mixed plantations. Environmental conditions were similar in the three types of tree stands $(P>0.05)$. Species richness and Shannon's diversity increased with increasing elevation and understory light availability $(P<0.05)$. Canonical Correspondence Analysis (CCA) showed that distribution of shrubs was determined by elevation, while herb distribution was related primarily to soil fertility followed by elevation. Based on the unchanged environmental conditions after establishment of larch plantations, we conclude that larch plantations had balancing effect on understory plant diversity.
\end{abstract}

Keywords: species richness; Shannon's diversity; environmental factors; larch plantations

\section{Introduction}

In recent decades, fast-growing tree species, such as eucalyptus (Gerber, 2011), rubber (Tan et al., 2011), poplar (Weih et al., 2003), and larch (Yu et al., 2006), have been used widely in forestation or reforestation to meet increasing demand for industrial timber and pulp. These tree species are often exotic and have a wider environmental adaptability than native trees (Turnbull, 1999). Therefore large-scale fast-growing tree plantations have provoked increasing concerns regarding their negative effects on plant diversity (Weih et al., 2003; Morris et al., 2008). Fast-growing tree plantations had lower plant diversity than crop lands (Weih et al., 2003; Britt et al., 2007) but greater species richness than abandoned fields (Lee et al., 2005; Boothroyd-Roberts et al., 2013). Tree plantations appear to have varied effects on understory plant diversity (Boothroyd-Roberts et al., 2013). To date, the extent to which understory plant diversity is affected by fast-growing tree plantations is still unclear.

Environmental change resulting from tree plantation has been recognized as a key factor driving the variation in understory plant diversity (Franklin and Steadman, 2010; Ibáñez and Gazol, 2010; Boothroyd-Roberts et al., 2013; D’Souza and Rodrigues, 2013). Compared to native tree species, fast-growing tree plantations often have lower under- 
story light availability and this might be the main reason for low plant diversity (Meers et al., 2010). Fast-growing tree plantations can result in low soil water content due to higher overstory transpiration rates and leading to low densities of hygrophytes (Boothroyd-Roberts et al., 2013; Li et al., 2014a). Additionally, change in soil fertility after tree plantation also affects understory plant diversity (Černý et al., 2013; Lima and Vieira, 2013). Low concentrations of organic matter and nutrients were the main reasons for low species richness in eucalypt plantations (Bargali et al., 1993). These environmental factors are recognized to be closely correlated with plant diversity. However, unlike in plains ecosystems, topography, such as elevation and slope, are important factors explaining variation of plant diversity in mountainous terrain (Ibáñez and Gazol, 2010). Links between environmental variables and plant diversity are relatively complicated in alpine forest.

Larix kaempferi, a fast-growing coniferous tree species, was introduced in the 1900s, to China from Japan. Due to its higher productivity than native trees, this species was extensively planted in the middle-high mountain areas in southern China. In the past 30 years, larches became the dominant coniferous tree species in forestation or reforestation in Hubei Province, raising concerns regarding the effects on plant diversity (Yu et al., 2006). However, some studies even showed that larches had greater species richness than broad-leaved tree species (Nagaike, 2002). It seems that larch plantations have balancing effect on understory plant diversity. Therefore we conducted a large-area investigation on three types of forest stands, viz. pure larch plantations (L. kaempferi), pure liriodendron plantations (Liriodendron chinense, a native broad-leaved deciduous tree species) and mixed stands (L. kaempferi and L. chinense), to test the effects of larch plantations on understory plant diversity.

\section{Materials and methods}

\section{Study site}

Our study was conducted in western Hubei Province, China. The site is characterized by a northern subtropical monsoon climate, with average annual temperature of $9-11^{\circ} \mathrm{C}$, frost-free days of 170-203 d, annual precipitation of 1,400-1,800 mm, and average humidity of 80-85\% (Cai, 2000; Lu and Chang, 2003). Since the 1960s, larch ( $L$. kaempferi) was planted extensively at this site due to its faster growth than native trees. Before establishment of these larch plantations, the dominant tree in these forests was Liriodendron chinense.

\section{Field investigation}

In September 2012, three stand types were chosen for this study: two pure stands ( $L$. kaempferi, L. chinense) and one mixed stand (L. kaempferi and L. chinense). The number of stands sampled in pure larch, pure liriodendron and mixed stands were 13, 3 and 3 , respectively (Table 1). In the middle of each stand, three plots $(20 \times 30 \mathrm{~m})$ were chosen as replications. Stand density, tree height and diameter at breast height (DBH) were measured. Stand age was determined from plantation records. Slope was measured using a gradient meter (XYPD01, China). The latitude, longitude, elevation and aspect were recorded using a global positioning system (GPS). Two illuminometers were used for measuring light availability at $1 \mathrm{~m}$ above the ground surface, one inside the plots (L1) and another in an open field (L2). The ratio of light availability (RLA) was calculated as 
the ratio of L1 to L2. A total of 40 paired-points were measured at each plot.

Table 1. Investigation areas of tree plantations in the subtropical forest ecosystem.

\begin{tabular}{|c|c|c|c|c|c|c|c|c|c|}
\hline $\mathrm{Nr}$. & Location & $\begin{array}{l}\text { Elevation } \\
\text { (m.a.s.l) }\end{array}$ & $\begin{array}{l}\text { Slope } \\
\left({ }^{\circ}\right)\end{array}$ & Aspect & $\begin{array}{l}\text { Age } \\
\text { (y) }\end{array}$ & $\begin{array}{l}\text { Density } \\
\left(\text { trees }^{-2} \mathrm{~m}^{-2}\right.\end{array}$ & $\begin{array}{l}\text { Height } \\
\text { (m) }\end{array}$ & $\begin{array}{c}\mathrm{DBH} \\
(\mathrm{cm})\end{array}$ & Stand types \\
\hline 1 & $\begin{array}{l}\mathrm{N} 31^{\circ} 04^{\prime} 44.3^{\prime \prime} \\
\text { E110 } \\
4^{\circ} 54^{\prime} 03.2^{\prime \prime}\end{array}$ & 1520 & 20 & Southwest & 21 & $1600.0 \pm 23.2$ & $14.8 \pm 5.4$ & $14.1 \pm 3.6$ & Pure larch \\
\hline 2 & $\begin{array}{l}\mathrm{N} 31^{\circ} 04^{\prime} 42.8^{\prime \prime} \\
\mathrm{E} 110^{\circ} 54^{\prime} 03.3^{\prime \prime}\end{array}$ & 1500 & 5 & Southwest & 21 & $1250.0 \pm 19.0$ & $14.9 \pm 4.4$ & $14.2 \pm 2.8$ & Pure larch \\
\hline 3 & $\begin{array}{l}\text { N31 } 1^{\circ} 04^{\prime} 49.8^{\prime \prime} \\
\text { E110 } \\
4^{\prime} 07.3^{\prime \prime}\end{array}$ & 1490 & 5 & Southwest & 21 & $1250.0 \pm 24.2$ & $12.9 \pm 4.5$ & $13.5 \pm 2.6$ & Pure larch \\
\hline 4 & $\begin{array}{l}\mathrm{N} 31^{\circ} 04^{\prime} 49.6^{\prime \prime} \\
\mathrm{E} 110^{\circ} 54^{\prime} 26.5^{\prime \prime}\end{array}$ & 1710 & 10 & Northwest & 21 & $1196.0 \pm 21.7$ & $16.0 \pm 4.1$ & $15.5 \pm 2.6$ & Pure larch \\
\hline 5 & $\begin{array}{l}\text { N31 }{ }^{\circ} 04^{\prime} 51.9^{\prime \prime} \\
\text { E110 } \\
\end{array}$ & 1720 & 25 & Northwest & 21 & $937.0 \pm 25.3$ & $15.1 \pm 3.2$ & $15.2 \pm 2.9$ & Pure larch \\
\hline 6 & $\begin{array}{l}\mathrm{N} 31^{\circ} 05^{\prime} 05.4^{\prime \prime} \\
\mathrm{E} 110^{\circ} 54^{\prime} 32.7^{\prime \prime}\end{array}$ & 1645 & 5 & Southwest & 21 & $1350.0 \pm 13.2$ & $14.7 \pm 4.5$ & $16.5 \pm 2.4$ & Pure larch \\
\hline 7 & $\begin{array}{l}\mathrm{N} 30^{\circ} 48^{\prime} 05.6^{\prime \prime} \\
\mathrm{E} 110^{\circ} 02^{\prime} 58.9^{\prime \prime}\end{array}$ & 1750 & 15 & Northwest & 26 & $1428.0 \pm 17.9$ & $24.2 \pm 3.8$ & $22.2 \pm 1.7$ & Pure larch \\
\hline 8 & $\begin{array}{l}\mathrm{N} 30^{\circ} 48^{\prime} 04.4^{\prime \prime} \\
\mathrm{E} 110^{\circ} 02^{\prime} 58.9^{\prime \prime}\end{array}$ & 1730 & 15 & South & 50 & $1448.0 \pm 19.3$ & $38.4 \pm 10.0$ & $28.1 \pm 3.2$ & Pure larch \\
\hline 9 & $\begin{array}{l}\mathrm{N} 30^{\circ} 48^{\prime} 05.7^{\prime \prime} \\
\mathrm{E} 110^{\circ} 02^{\prime} 51.6^{\prime \prime}\end{array}$ & 1770 & 5 & East & 24 & $1750.0 \pm 20.3$ & $19.6 \pm 2.8$ & $20.0 \pm 2.2$ & Pure larch \\
\hline 10 & 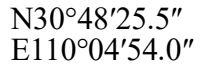 & 1690 & 15 & Southeast & 19 & $1052.0 \pm 15.2$ & $13.3 \pm 3.2$ & $12.7 \pm 2.0$ & Pure larch \\
\hline 11 & $\begin{array}{l}\mathrm{N} 30^{\circ} 48^{\prime} 37.3^{\prime \prime} \\
\mathrm{E} 110^{\circ} 05^{\prime} 02.4^{\prime \prime}\end{array}$ & 1709 & 8 & Southeast & 19 & $2828.0 \pm 28.6$ & $14.4 \pm 3.8$ & $14.4 \pm 2.7$ & Pure larch \\
\hline 12 & $\begin{array}{l}\mathrm{N} 30^{\circ} 42^{\prime} 10.8^{\prime \prime} \\
\mathrm{E} 109^{\circ} 40^{\prime} 56.1^{\prime \prime}\end{array}$ & 1870 & 15 & South & 27 & $2941.0 \pm 33.5$ & $23.4 \pm 3.3$ & $20.6 \pm 1.6$ & Pure larch \\
\hline 13 & $\begin{array}{l}\mathrm{N} 30^{\circ} 42^{\prime} 48.6^{\prime \prime} \\
\mathrm{E} 109^{\circ} 40^{\prime} 22.0^{\prime \prime}\end{array}$ & 1930 & 12 & East & 13 & $2222.0 \pm 28.4$ & $8.3 \pm 1.4$ & $9.0 \pm 0.9$ & Pure larch \\
\hline 14 & $\begin{array}{l}\mathrm{N} 31^{\circ} 05^{\prime} 04.8^{\prime \prime} \\
\mathrm{E} 110^{\circ} 54^{\prime} 34.0^{\prime \prime}\end{array}$ & 1630 & 30 & Northeast & 21 & $1550.0 \pm 27.6$ & $10.3 \pm 4.5$ & $10.4 \pm 3.8$ & $\begin{array}{l}\text { Pure lirio- } \\
\text { dendron }\end{array}$ \\
\hline 15 & $\begin{array}{l}\mathrm{N} 31^{\circ} 04^{\prime} 57.5^{\prime \prime} \\
\text { E110 } \\
\end{array}$ & 1750 & 8 & Southeast & 21 & $1060.0 \pm 32.7$ & $23.2 \pm 8.1$ & $16.9 \pm 2.9$ & $\begin{array}{l}\text { Pure lirio- } \\
\text { dendron }\end{array}$ \\
\hline 16 & $\begin{array}{l}\mathrm{N} 30^{\circ} 42^{\prime} 16.2^{\prime \prime} \\
\mathrm{E} 109^{\circ} 41^{\prime} 18.5^{\prime \prime}\end{array}$ & 1790 & 20 & South & 24 & $1428.0 \pm 18.6$ & $15.8 \pm 4.4$ & $16.0 \pm 3.2$ & $\begin{array}{l}\text { Pure lirio- } \\
\text { dendron }\end{array}$ \\
\hline 17 & 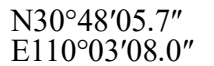 & 1730 & 15 & North & 24 & $1250.0 \pm 21.4$ & $18.5 \pm 5.4$ & $15.7 \pm 2.1$ & $\begin{array}{l}\text { Mixed } \\
\text { stands }\end{array}$ \\
\hline 18 & $\begin{array}{l}\mathrm{N} 30^{\circ} 48^{\prime} 01.9^{\prime \prime} \\
\mathrm{E} 110^{\circ} 02^{\prime} 57.2^{\prime \prime}\end{array}$ & 1780 & 30 & North & 25 & $1400.0 \pm 23.1$ & $17.2 \pm 4.2$ & $17.2 \pm 2.3$ & $\begin{array}{l}\text { Mixed } \\
\text { stands }\end{array}$ \\
\hline 19 & $\begin{array}{l}\mathrm{N} 30^{\circ} 42^{\prime} 38.8^{\prime \prime} \\
\mathrm{E} 109^{\circ} 40^{\prime} 38.5^{\prime \prime}\end{array}$ & 1890 & 30 & West & 25 & $1577.0 \pm 19.7$ & $17.5 \pm 4.9$ & $17.7 \pm 2.0$ & $\begin{array}{l}\text { Mixed } \\
\text { stands }\end{array}$ \\
\hline
\end{tabular}

A nested sub-plot sampling design described by Avery and Burkhart (1983) was used to form sampling units to determine plant diversity. In each plot, 4 quadrats $(2 \times 2 \mathrm{~m})$ in upper, middle and lower parts of slope were chosen for investigation. The total number of sampling quadrats in each plot was 12. The species name, number and coverage of each species at each sampling quadrat were recorded. Plant coverage was determined by visual estimate.

\section{Soil fertility analysis}

In each plot, soil in the upper $40 \mathrm{~cm}$ profile was sampled according to a 5-point sampling method (Pobel et al., 2011) and then immediately transported to laboratory for measurement. Six parameters, including $\mathrm{pH}$, soil water content (SWC), soil organic matter (SOM), soil total nitrogen (STN), soil total phosphorus (STP), and soil total potassium (STK), were quantified. Soil $\mathrm{pH}$ was measured in solution with 1: $2.5(\mathrm{w} / \mathrm{v})$ of soil to distilled water using a Mettler Toledo Delta $320 \mathrm{pH}$ Meter. SWC was measured using the classical method of drying and weighing (Dobriyal et al., 2012). SOM, STN, STP and STK were measured by wet digestion of potassium dichromate oxidation 
(Rayment and Higginson, 1992), semi-micro Kjeldahl method (Bao, 1999), $\mathrm{NaOH}$ fusion and colorimetric procedures (Olsen and Sommers, 1982), and $\mathrm{NaOH}$ melting-flaming luminosity method (Chen et al., 2007), respectively.

\section{Data analysis}

Understory plant diversity was quantified using species richness and Shannon's diversity index $(\mathrm{H})$. Species richness was calculated as number of species per sampling quadrat (Magurran, 1998; Weih et al., 2003). H was calculated according to the following equation (Magurran, 1998):

$$
H=-\sum_{i=1}^{N} P_{i} \ln p_{i}
$$

Where, $\mathrm{H}$ indicates Shannon's diversity index; N, species number; $\mathrm{Pi}$, the proportion of species $i$ relative to the total number of species.

Important Value Index (IV) was determined according to the equation (Misra, 1968):

$$
I V_{i}=\left(R D_{i}+R C_{i}+R F_{i}\right) / 3
$$

Where $\mathrm{IV}_{\mathrm{i}}$ indicates the importance value index of the $i$ th species; $\mathrm{RD}_{\mathrm{i}}$, the relative density; $\mathrm{RC}_{\mathrm{i}}$, relative coverage; $\mathrm{RF}_{\mathrm{i}}$, relative frequency.

General linear model (GLM) of plant diversity, ratio of light availability, and soil fertility among three types of tree stands were analyzed at the 0.05 significance level. Homogeneity of variances was tested using Levene's test, and data were $\log _{10}$-transformed where necessary to reduce the heterogeneity of variances. The relationships between plant diversity (species number, Shannon's diversity) and 9 environmental variables (elevation, slope, RLA, pH, SWC, SOM, STN, STP, and STK) were analyzed by curve regression with $\mathrm{R}^{2}$ and $P$ values. All were performed using SPSS V17.0 (SPSS Inc., USA).

To explore the relationship between environmental variables and two growth forms (shrubs, herbs), a canonical correspondence analysis (CCA) was performed using the software CANOCO 4.5 (Microcomputer Power Ithaca, NY, USA). The vegetations data matrix consisted of the IV of species with frequency $>5 \%$ and the environmental data matrix consisted of 9 environmental variables.

\section{Results}

\section{Species number and Shannon's diversity}

Species richness was similar for the three stand types $(P>0.05$, Table 2$)$. Shannon's diversity was higher in mixed stands (1.91) than in pure liriodendron (1.44) or pure larch (1.17). It was clear those larches had no significant effects on species richness, but supported a greater Shannon's diversity in mixed stands. 
Table 2. ANOVA of plant diversity, ratio of light availability, and soil fertility (means \pm S.E.) in three stand types

\begin{tabular}{lllll}
\hline Variables & Pure larch & Pure liriodendron & Mixed stands & $P$ value \\
\hline $\mathrm{pH}$ & $4.94 \pm 0.21$ & $4.93 \pm 0.07$ & $5.50 \pm 0.29$ & 0.171 \\
Soil water content $(\%)$ & $5.79 \pm 0.35$ & $6.30 \pm 0.31$ & $5.86 \pm 0.49$ & 0.683 \\
Soil organic matter $(\mathrm{g} / \mathrm{kg})$ & $53.73 \pm 3.08$ & $79.44 \pm 5.99$ & $51.52 \pm 7.77$ & 0.353 \\
Soil total nitrogenous $(\mathrm{g} / \mathrm{kg})$ & $2.77 \pm 0.22$ & $3.55 \pm 0.49$ & $3.15 \pm 0.16$ & 0.309 \\
Soil total phosphorous $(\mathrm{g} / \mathrm{kg})$ & $1.21 \pm 0.09$ & $1.55 \pm 0.21$ & $1.38 \pm 0.08$ & 0.311 \\
Soil total potassium $(\mathrm{g} / \mathrm{kg})$ & $1.00 \pm 0.08$ & $1.29 \pm 0.18$ & $1.14 \pm 0.06$ & 0.309 \\
Ratio of light availability $(\%)$ & $25.17 \pm 2.13$ & $27.30 \pm 1.15$ & $26.03 \pm 2.38$ & 0.753 \\
Species number & $6.37 \pm 0.10$ & $7.53 \pm 0.91$ & $9.64 \pm 1.31$ & 0.111 \\
Shannon's diversity & $1.17 \pm 0.04$ & $1.44 \pm 0.16$ & $1.91 \pm 0.18$ & $\mathbf{0 . 0 2 9}$ \\
\hline
\end{tabular}

\section{Light availability and soil fertility}

Understory light availability was similar in the three stand types $(P>0.05$, Table 2$)$. Soil fertility $(\mathrm{pH}$, water content, organic matter, total nitrogen, total phosphorus and total potassium) was also similar in the three stand types.

\section{Regression between plant diversity and environmental variables}

Species richness and Shannon's diversity increased with increasing elevation and light availability. All other environmental variables were unrelated to both indices (Fig. 1).

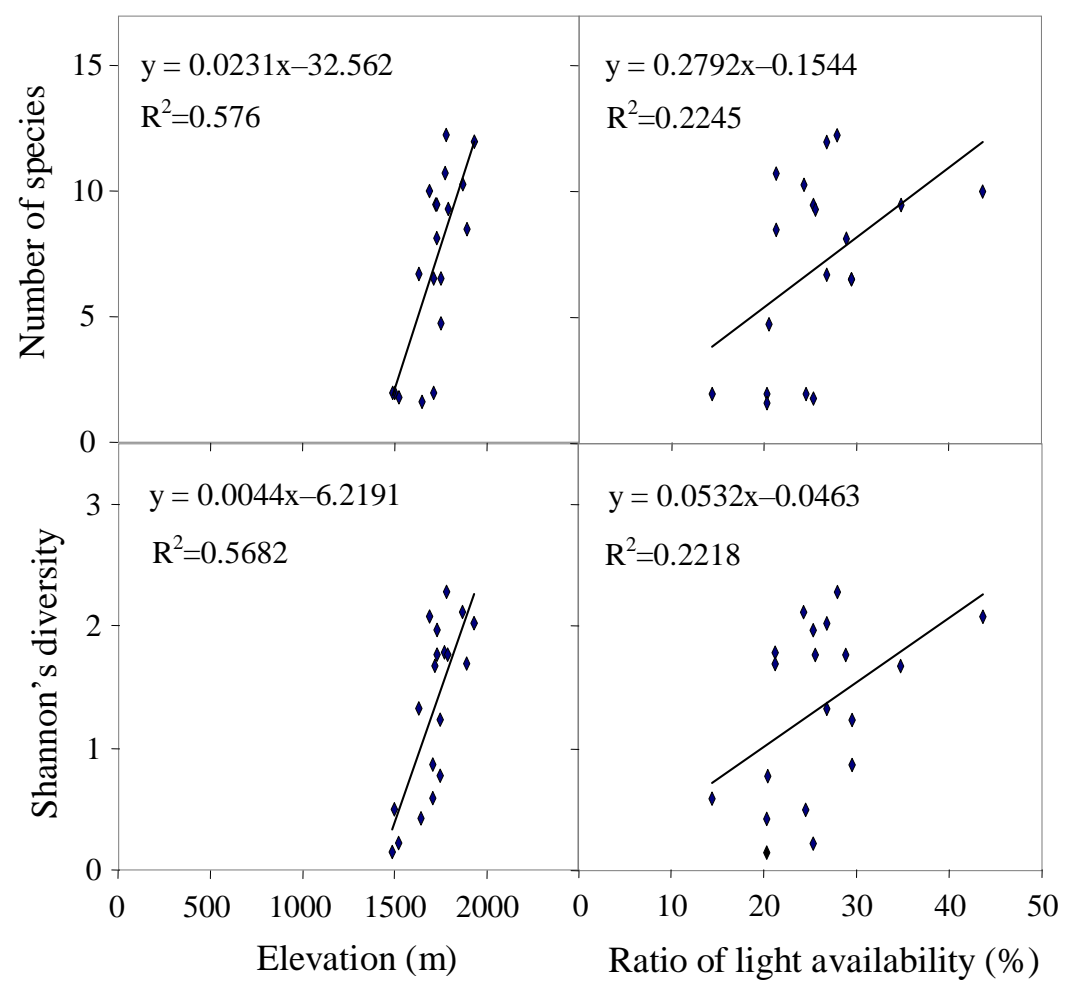

Figure 1. Relationships between plant diversity and environmental variables. Only significant regressions are shown. 


\section{Canonical Correspondence Analysis (CCA) between environmental variables and plant species}

For shrubs, species-environment correlation coefficient was 0.962 in the first axis and 0.900 in the second axis (Table 3, Fig. 2). The first and second axes explained almost $28.2 \%$ and $20.7 \%$ of the variance of species-environment relationships. The first axis was negatively correlated with elevation $(P<0.001)$. The second axis was not significantly correlated with any environmental variables. Species, such as Weigela japonica and Rubus corchorifolius, distributed at the left of Axis 2, were closely related to higher elevation. Other species, such as Chimonobambusa quadrangularis and Stauntonia chinensis, distributed at the right of Axis 2, were closely associated with lower elevation.

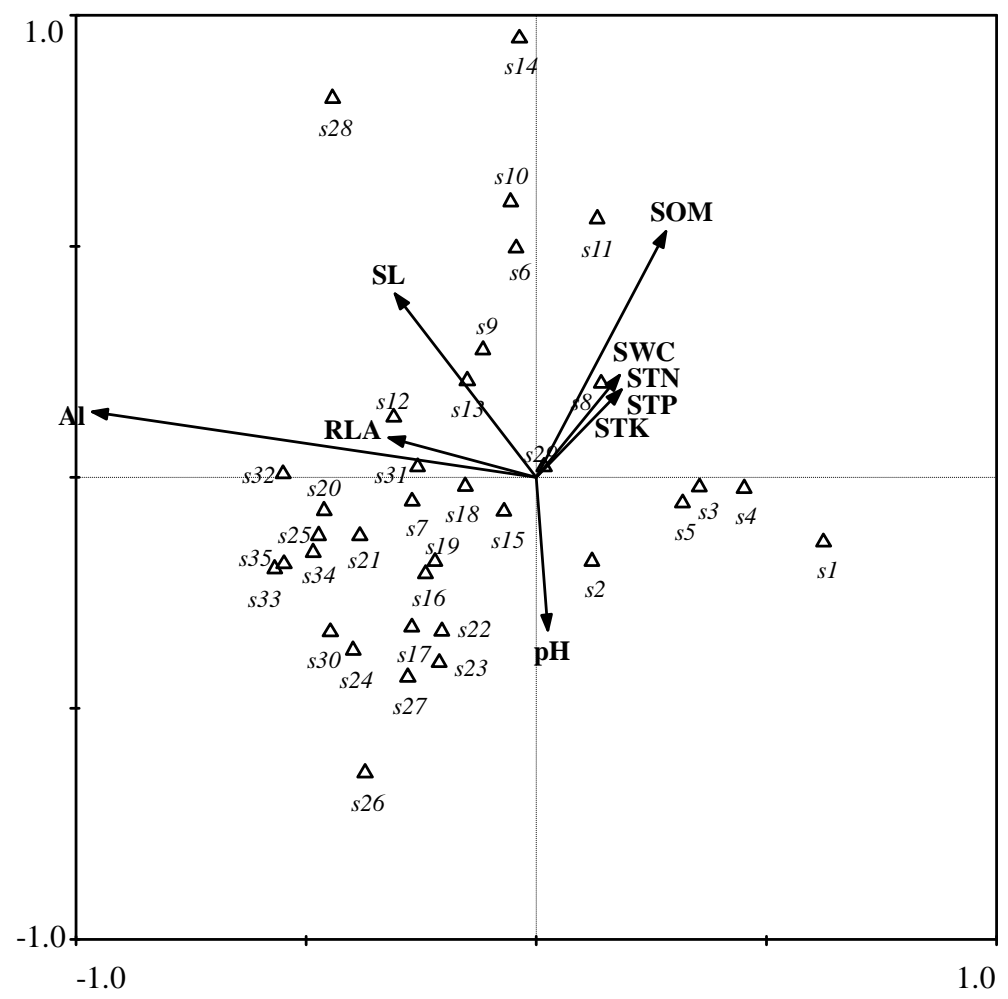

Figure 2. CCA ordination (Axis 1 by Axis 2) with shrubs and environmental variables. Only shrubs with frequency over $5 \%$ are shown. The arrows and points indicate the environmental variables and the plants respectively. S1, Chimonobambusa quadrangularis; S2, Smilax china; S3, Clerodendrum cyrtophyllum; S4, Stauntonia chinensis; S5, Rosa multiflora; S6, Fargesia spathacea; S7, Rubus corchorifolius; S8, Lonicera japonica; S9, Lindera glauca; S10, Corylopsis sinensis; S11, Ilex pernyi; S12, Euonymus alatus; S13, Lonicera maackii; S14, Callicarpa rubella; S15, Hydrangea macrophylla; S16, Decaisnea insignis; S17, Lonicera trichosantha;

S18, Indocalamus tessellates; S19, Smilax glabra; S20, Actinidia chinensis; S21, Spiraea salicifolia; S22, Elaeagnus umbellate; S23, Rubus pinfaensis; S24, Hydrangea longipes; S25,

Schisandra chinensis; S26, Viburnum plicatum; S27, Psilopeganum sinensis; S28, Morus australis; S29, Lycium chinense; S30, Cerasus tomentosa; S31, Mahonia fortunei; S32, Lespedeza bicolor; S33, Weigela japonica; S34, Rubus rosaefolius; S35, Rubus corchorifolius.

For herbs, species-environment correlation coefficient was 0.950 in the first axis and 0.945 in the second axis (Table 3, Fig. 3). The first and second axes explained almost 
$24.5 \%$ and $19.9 \%$ of the variance of species-environment relationships. The first axis was positively correlated with SOM $(P<0.001)$, STN $(P<0.05)$, STP $(P<0.05)$ and STK $(P<0.05)$. The second axis was negatively associated with elevation $(P<0.01)$. Species, such as Trifolium pratense and Bupleurum longiradiatum, distributed at the left of axis 2, were closely related to lower SOM, STN, STP and STK. Other species, such as Impatiens balsamina and Geranium wilfordii, distributed at the right of Axis 2, were closely correlated with higher SOM, STN, STP and STK. In the top of Axis 1, species, such as Pilea notata and Viola phalacrocarpa, were associated with lower latitude. However, in the lower of Axis 1, Polystichum herbaceum and Carex pallida, were correlated with higher latitude.

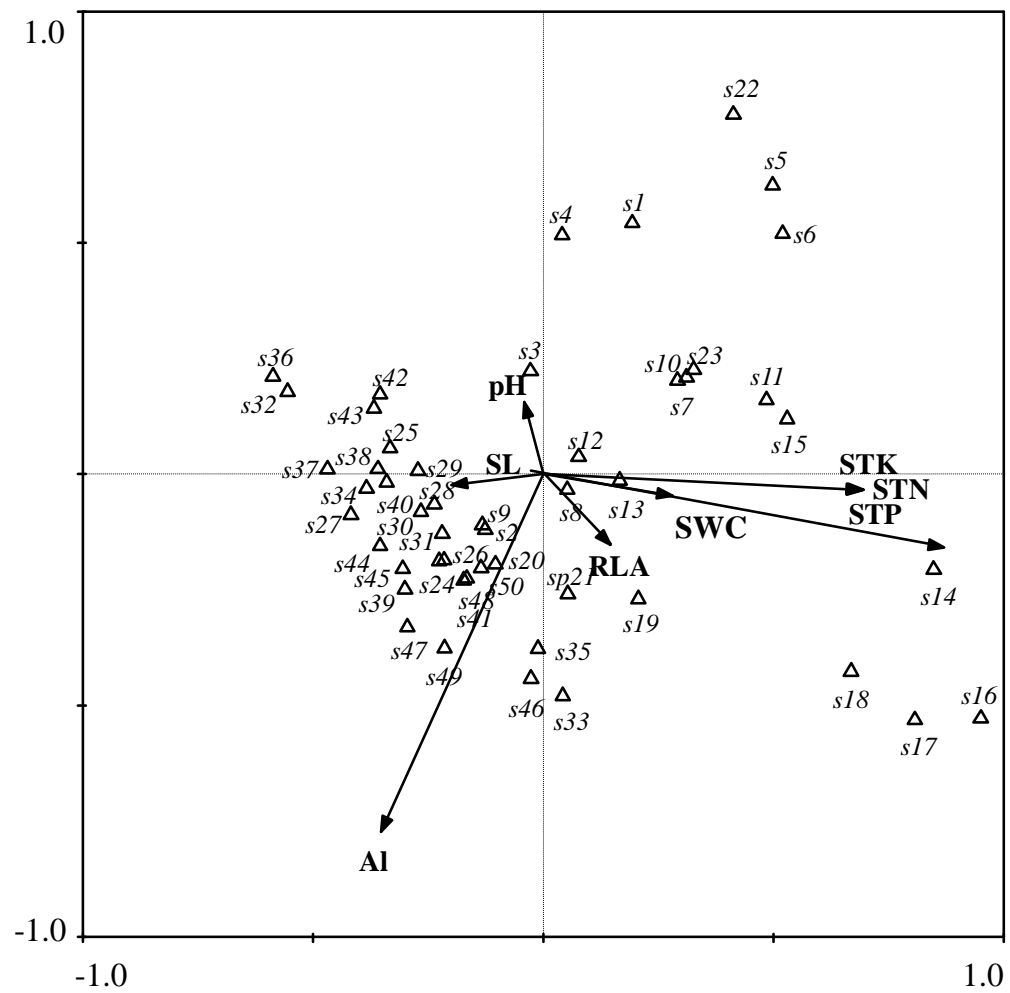

Figure 3. CCA ordination (Axis 1 by Axis 2) with herbs and environmental variables. Only herbs with frequency over $5 \%$ are showed. The arrows and points indicate the environmental variables and the plants respectively. S1, Senecio scandens; S2, Viola diffusa; S3, Cyperus stoloniferus; S4, Cyclospermum leptophyllum; S5, Viola phalacrocarpa; S6, Antenoron filiforme; S7, Epimedium sagittatum; S8, Cyperus rotundus; S9, Parathelypteris glanduligera; S10, Asparagus filicinus;

S11, Cyclosorus interruptus; S12, Clematis florida; S13, Cyperus iria; S14, Euphorbia pekinensis; S15, Liriope spicata; S16, Impatiens balsamina; S17, Geranium wilfordii; S18, Agrimonia pilosa; S19, Galium spurium; S20, Chrysanthemum indicum; S21, Reineckea carnea; S22, Pilea notata; S23, Athyrium iseanum; S24, Galium bungei; S25, Impatiens davidi; S26, Lysimachia pentapetala; S27, Athyrium otophorum; S28, Selaginella uncinata; S29, Hemsleya sphaerocarpa; S30, Houttuynia cordata; S31, Gentiana leptoclada; S32, Trifolium pratense;

S33, Polystichum herbaceum; S34, Astilbe chinensis; S35, Botrychium virginianum; S36, Bupleurum longiradiatum; S37, Carex tristachya; S38, Matteuccia orientalis; S39, Polygonatum odoratum; S40, Phyllostachys heteroclada; S41, Polystichum makinoi; S42, Carex hattoriana; S43, Tiarella polyphylla; S44, Viola thomsonii; S45, Botrychium ternatum; S46, Carex pallida;

S47, Osmunda japonica; S48, Clematis repens; S49, Dryopteris chinensis; S50, Potentilla kleiniana. 
Table 3. Correlations between ordination axes and environmental variables in 19 plantation areas.

\begin{tabular}{|c|c|c|c|c|}
\hline \multirow{2}{*}{$\begin{array}{l}\text { Environmental } \\
\text { variables }\end{array}$} & \multicolumn{2}{|l|}{ Shrubs } & \multicolumn{2}{|l|}{ Herbs } \\
\hline & Axis-1 & Axis-2 & Axis-1 & Axis-2 \\
\hline Elevation & $-0.9635^{* * * *}$ & 0.1416 & -0.3552 & $-0.7733 * *$ \\
\hline Slope & -0.3067 & 0.3979 & -0.1989 & -0.0232 \\
\hline $\mathrm{pH}$ & 0.0245 & -0.3315 & -0.0416 & 0.1564 \\
\hline Soil water content & 0.1802 & 0.2204 & 0.2807 & -0.0463 \\
\hline Soil organic matter & 0.2808 & 0.5314 & $0.8703 * * *$ & -0.1584 \\
\hline Soil total nitrogen & 0.1846 & 0.1898 & $0.6931 *$ & -0.0346 \\
\hline Soil total phosphorous & 0.1831 & 0.1919 & $0.6920 *$ & -0.0333 \\
\hline Soil total potassium & 0.1882 & 0.1928 & $0.6959 *$ & -0.0330 \\
\hline Ratio of light availability & -0.3209 & 0.0852 & 0.1463 & -0.1529 \\
\hline Species-environment correlations & 0.962 & 0.900 & 0.950 & 0.945 \\
\hline $\begin{array}{l}\text { Cumulative percentage variance of species-environment } \\
\text { relation }\end{array}$ & 28.2 & 48.9 & 24.5 & 44.4 \\
\hline
\end{tabular}

\section{Discussion}

Species richness and Shannon's diversity were similar in pure larch and pure liriodendron plantations, indicating that the effects of larch plantations on understory plant communities were similar to those of liriodendron plantations. This was different from the most previous results, which showed that fast-growing tree plantations could result in low plant diversity (Elek et al., 2010; Meers et al., 2010). No significant difference in plant diversity between larches and liriodendron was due to the similar understory light availability and soil fertility (Nagaike et al., 2003; Lei et al., 2007; Li et al., 2014).

Environmental conditions are recognized the key factors for understory plant diversity (Aber and Melillo, 2001; Černý et al., 2013). In our study, species richness and Shannon's diversity were positively correlated with the elevation and ratio of light availability. High elevation contributed to a wide range of habitat, especially for temperature and heat (Černý et al., 2013; Khan et al., 2013), which indicated that more ecological niches could be provide for the establishment of plant species. High light availability indicated that low competition among understory plants and more species can survive (Archaux et al., 2010; Boothroyd-Roberts et al., 2013).

Plants distribution was significantly associated with environmental variables (Gazol and Ibáñez, 2010). In this study, elevation was the most important factors for determining vegetation distribution, which was consistent with the previous studies (Aber and Melillo, 2001; Černý et al., 2013). CCA results showed that most shrubs species distributed in the left of Axis 2, such as Lespedeza bicolor, and Rubus rosaefolius, suggesting that these species survive in habitats with relatively higher elevation. In addition to elevation, soil nutrition also played an important role in plant distribution (Hokkanen, 2006; Cao et al., 2009). Most herbs species located in the left of Axis 2, such as Carex tristachya, and Matteuccia orientalis, suggesting that these species usually lived in habitat with relatively lower organic matter and total nitrogen. Additionally, the responses of plant distribution to environmental variables were different between two growth forms: shrubs were determined by elevation, while herbs primarily by soil fertility, followed by elevation. Compared to shrubs, herbs distribution was easily affected by local environments (Bhattarai and Vetaas, 2003; Lu et al., 2006). 
As a fast-growing tree, larch plantations had balancing effect on understory plant diversity in the subtropical forest ecosystems, China. Studies even showed that larches increased species richness compared to Quercus crispula (Nagaike, 2002; Nagaike et al., 2006). Balancing effect of larch plantations on understory plant diversity was due to the unchanged environment after establishment of larch plantations.

Acknowledgments. This study was financially supported by the International Science \& Technology Cooperation Program of China (2012DFB30030).

\section{REFERENCE}

[1] Aber, J.D., Melillo, J.M. (2001): Terrestrial Ecosystems, second ed. - San Diego: Academic Press.

[2] Archaux, F, Chevalier, R., Berthelot, A. (2010): Towards practices favourable to plant diversity in hybrid poplar plantations. - Forest Ecology and Management 259: 2410-2417.

[3] Avery, T.E., Burkhart, H.E. (1983): Forest measurements. New York: McGraw-Hill.

[4] Bao, S.D. (1999): Chemical analysis of agriculture soil. - Beijing: Science Press. (in Chinese)

[5] Bargali, S.S., Singh, R.P., Joshi, M. (1993): Changes in soil characteristics in eucalypt plantations replacing natural broad-leaved forests. Journal of Vegetation Science, 4: $25-28$.

[6] Bhattarai, K.R., Vetaas, O.R. (2003): Variation in plant species richness of different life forms along a subtropical elevation gradient in the Himalayas, east Nepal. - Global Ecology and Biogeography 12: 327-340.

[7] Boothroyd-Roberts, K., Gagnon, D., Truax, B. (2013): Can hybrid poplar plantations accelerate the restoration of forest understory attributes on abandoned fields? - Forest Ecology and Management 287: 77-89.

[8] Britt, C.P., Fowbert, J., McMillan, S.D. (2007): The ground flora and invertebrate fauna of hybrid poplar plantations: results of ecological monitoring in the PAMUCEAF project. - Aspects of Applied Biology 82: 83-90.

[9] Cai, S., Liu, X., Zhang, J., Zhou, X., Zhang, X. (2000): Community characteristics of rare trees at Dalaoling of Three-Gorge reservoir area in western Hubei Province. - Chinese Journal of Applied Ecology 2: 165-168.

[10] Cao, J.F., Ma, K.M., Feng, Z.W., Qi, J., Feng, Y. (2009): Coupling effects of elevation and human disturbance on landscape and plant diversity in the vicinity of mountain villages of Beijing, China. - Acta Ecology Sinica 29: 56-61.

[11] Černý, T., Doležal, J., Janeček, Š., Šrůtek, M., Valachovič, M., Petř́k, P., Altman, J., Bartoš, M., Song, J.S. (2013): Environmental correlates of plant diversity in Korean temperate forests. - Acta Oecologica 47: 37-45.

[12] Chen, Y.N., Wang, Q., Li, W.H., Ruan, X. (2007): Microbiotic crusts and their interrelations with environmental factors in the Gurbantonggut desert, western China. - Environmental Geology 52: 691-700

[13] D'Souza, J., Rodrigues, B.F. (2013): Biodiversity of Arbuscular Mycorrhizal (AM) fungi in mangroves of Goa in West India. - Journal of Forestry Research 24: 515-523.

[14] Dobriyal, P., Qureshi, A., Badola, R., Hussain, S.A. (2012): A review of the methods available for estimating soil moisture and its implications for water resource management. Journal of Hydrology, 458-459: 110-117.

[15] Elek, Z., Dauffy-Richard, E., Gosselin, F. (2010): Carabid species responses to hybrid poplar plantations in floodplains in France. - Forest Ecology and Management 260: 
1446-1455.

[16] Franklin, J., Steadman, D.W. (2010). Forest plant and bird communities in the Lau Group, Fiji. - PloS one 5: e15685, 1-14.

[17] Gazol, A., Ibáñez, R. (2010): Variation of plant diversity in a temperate unmanaged forest in northern Spain: behind the environmental and spatial explanation.- Plant Ecology 207: $1-11$.

[18] Gerber, J.F. (2011): Conflicts over industrial tree plantations in the South: Who, how and why? - Global Environmental Change 21: 165-176.

[19] Hokkanen, P. (2006): Environmental patterns and gradients in the vascular plants and bryophytes of eastern Fennoscandian herb-rich forests. - Forest Ecology and Management 229: 73-87.

[20] Ibáñez, R., Gazol, A. (2010): Variation of plant diversity in a temperate unmanaged forest in northern Spain: behind the environmental and spatial explanation.- Plant Ecology 207: $1-11$.

[21] Khan, N., Shaukat, S.S., Ahmed, M., Siddiqui, M.F. (2013): Vegetation-environment relationships in the forests of Chitral district Hindukush range of Pakistan. - Journal of Forestry Research 24: 205-216.

[22] Lee, E.W.S., Hau, B.C.H., Corlett, R.T. (2005): Natural regeneration in exotic tree plantations in Hong Kong, China. - Forest Ecology and Management 212: 358-366.

[23] Lei, X., Lu, Y., Peng, C., Zhang, X., Chang, J., Hong, L. (2007): Growth and structure development of semi-natural larch-spruce-fir (Larix olgensis-Picea jezoensis-Abies nephrolepis) forests in northeast China: 12-year results after thinning. - Forest Ecology and Management 240: 165-177.

[24] Li, Y., Qin, H., Xie, Y., Wang, W., Chen, X., Zhang, C. (2014a): Physiological mechanism for the reduction in soil water in poplar (Populus deltoides) plantations in Dongting Lake wetlands. - Wetlands Ecology and Management 22: 25-33.

[25] Li, Y., Chen, X., Xie, Y., Li, X., Li, F., Hou, Z.Y. (2014b): Effects of young poplar plantations on understory plant diversity in the Dongting Lake wetlands, China. - Scientific Reports 4, doi: 10.1038/srep06339.

[26] Lima, T.A., Vieira, G. (2013): High plant species richness in monospecific tree plantations in the Central Amazon. - Forest Ecology and Management 295: 77-86.

[27] Lu, S.P., Chang, S. (2003): Appraising about the niche of the forest resources in Gaoyanzi Forestry Center. - Journal of Hubei Institute for Nationalities (Natural Science Edition) 2: 22-24. (in Chinese)

[28] Lu, T., Ma, K.M., Zhang, W.H., Fu, B.J. (2006): Differential responses of shrubs and herbs present at the Upper Minjiang River basin (Tibetan Plateau) to several soil variables. - Journal of Arid Environments 67: 373-390.

[29] Magurran, A.E. (1998): Ecological diversity and its measurement. - London: Princeton University Press.

[30] Meers, T., Kasel, S., Bell, T.L., Enright, N.J. (2010): Conversion of native forest to exotic Pinus radiata plantation: Response of understory plant composition using a plant functional trait approach. - Forest Ecology and Management 259: 399-409.

[31] Misra, R. (1968): Ecology Work Book. - New Delhi: Oxford and IBH publishing Company.

[32] Morris, T.L., Witkowski, E.T.F., Coetzee, J.A. (2008): Initial response of riparian plant community structure to clearing of invasive alien plants in Kruger National Park, South Africa. - South African Journal of Botany 74: 485-494.

[33] Nagaike, T., Hayashi, A., Abe, M., Arai, N. (2003): Differences in plant species diversity in Larix kaempferi plantations of different ages in central Japan. - Forest Ecology and Management 183: 177-193.

[34] Nagaike, T., Hayashi, A., Kubo, M., Takahashi, K., Abe, M., Arai, N. (2006): Changes in plant species diversity over 5 years in Larix kaempferi plantations and abandoned coppice forests in central Japan. - Forest Ecology and Management 236: 278-285. 
[35] Nagaike, T. (2002): Differences in plant species diversity between conifer (Larix kaempferi) plantations and broad-leaved (Quercus crispula) secondary forests in central Japan. - Forest Ecology and Management 168: 111-123.

[36] Olsen, S.R., Sommers, L.E. (1982): Phosphorus. - In: Page AL, Miller RH, Keene DR (eds), Methods of soil analysis. Madison: Soil Science Society of America, pp 403-448.

[37] Pobel, D., Robin, J., Humbert, J.F. (2011): Influence of sampling strategies on the monitoring of cyanobacteria in shallow lakes: Lessons from a case study in France. - Water Research 45: 1005-1014.

[38] Rayment, G.E., Higginson, F.R. (1992): Australian Laboratory handbook of soil and water chemical methods. - Melbourne, Inkata Press.

[39] Tan, Z.H., Zhang, Y.P., Song, Q.H., Liu, W.J., Deng, X.B., Tang, J.W., Deng, Y., Zhou, W.J., Yang, L.Y., Yu, G.R., Sun, X.M., Liang, N.S. (2011): Rubber plantations act as water pumps in tropical China. - Geophysical Research Letters 38: L24406.

[40] Turnbull, J.W. (1999): Eucalypt plantations. - New Forests 17: 37-52.

[41] Weih, M., Karacic, A., Munkert, H., Verwijst, T., Diekmann, M. (2003): Influence of young poplar stands on floristic diversity in agricultural landscapes (Sweden). - Basic and Applied Ecology 4: 149-156.

[42] Yu, X.D., Luo, T.H., Zhou, H.Z. (2006): Distribution of carabid beetles among regenerating and natural forest types in Southwest China. - Forest Ecology and Management 231: 169-177. 